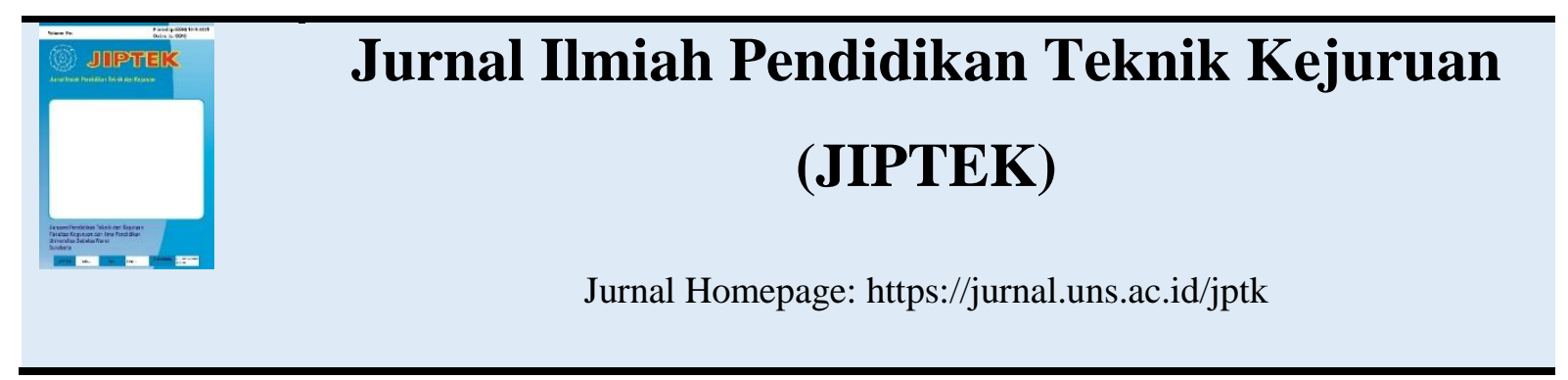

\title{
PENGARUH FASILITAS BELAJAR BERBASIS TEKNOLOGI TERHADAP PRESTASI BELAJAR SISWA
}

\author{
Havid Muhamad ${ }^{1}$, Efendi Agus ${ }^{2}$, Basori ${ }^{3}$ \\ 1,2,3Program Studi Pendidikan Teknik Informatika dan Komputer, FKIP, Universitas Sebelas Maret \\ Surakarta \\ Jalan Ahmad Yani 200 Surakarta \\ Email: havidkonoha@gmail.com
}

\begin{abstract}
ABSTRAK
Pendidikan sangat penting bagi kita, negara bisa maju karena orang-orangnya berpendidikan. Keberhasilan pendidikan ditentukan oleh kualaitas pendidikan itu sendiri. Untuk mengetahui kualitas pendidkan diperlukan suatu hasil atau prestasi. Salah satu faktor yang mempengaruhi prestasi adalah fasilitas. Tujuan penelitian ini adalah untuk mengetahui adakah pengaruh fasilitas belajar terhadap prestasi belajar siswa. Pengambilan sample menggunakan sistem simple random sampling sebanyak 58 orang dari total populasi keseluruhan sebanyak 70 orang pada jenjang pendidikan formal. Metode yang digunakan dalam pengambilan data yaitu menggunakan quisioner, observasi dan dokumentasi. Teknik analisis data yang digunakan yaitu menggunakan analisis regresi linear sederhana. Berdasarkan hasil analisis data dan pengujian hipotesis diketahui bahwa kedua variabel yaitu fasilitas belajar (X) dan prestasi belajar siswa (Y) mempunyai pengaruh yang positif, hal ini dibuktikan dengan $r=0,277$ dimana pedoman yang digunakan untuk memberikan interpretasi yang dikemukakan oleh Sugiyono berada pada interval 0,20 - 0,399 yang mana termasuk dalam kategori rendah. Berdasarkan hasil penelitian yang telah dikemukakan oleh penulis yang mana terdapat pengaruh antara fasilitas belajar terhadap prestasi belajar dengan kategori rendah, maka perlu ditingkatkan efektifitas penggunaan fasilitas belajar serta dilakukan penelitian lain tentang faktor lain yang mempengaruhi prestasi belajar siswa selain fasilitas belajar.
\end{abstract}

Kata kunci: pengaruh fasilitas belajar, fasilitas belajar, teknologi, product moment

\begin{abstract}
Education is very important for us, the country can go forward because the people are educated. The success of education is determined by the quality of education itself. To know the quality of education required a result or achievement. One of the factors affecting achievement is the facility. The purpose of this study is to determine whether there is influence of learning facilities on student achievement. Sampling using simple random sampling system as much as 58 people from the total population as much as 70 people at the level of formal education. The method used in data collection that is using quisioner, observation and documentation. Data analysis technique used is using simple linear regression analysis. Based on the results of data analysis and hypothesis testing it is known that the two variables of learning facilities $(X)$ and student learning achievement $(Y)$ have a positive influence, this is evidenced by $r=0.277$ where the guidelines used to provide interpretation proposed by Sugiyono are at intervals $0.20-0.399$ which fall into the low category. Based on the results of research that has been put forward by the authors which there is influence between learning facilities on learning achievement with low categories, it is necessary to improve the effectiveness of the use of learning facilities and conducted other research on other factors that affect student achievement in addition to learning facilities.
\end{abstract}

Keywords: the influence of learning facilities, learning facilities, technology, product moment 


\section{PENDAHULUAN}

Pendidikan memanglah sangat penting bagi kita, menurut UUD 1945 pasal 31 yaitu setiap warga negara berhak mendapatkan pendidikan, pendidikan bukan hanya merupakan pilar penting dalam upaya mencerdaskan bangsa, tetapi juga merupakan syarat mutlak bagi peningkatan kesejahteraan masyarakat yang berkeadilan. Di dalam semua jenjang permasalah pendidikan di Indonesia hampir sama. Mutu pendidikan di Indonesia berdasarkan data UNESCO 2011 menduduki peringkat 69 dari 127 negara. Pada 2012 menjadi peringkat 64 dari 120 negara, dan pada 2013 naik tiga peringkat menjadi 121 dari 185 negara. Berdasarkan data tersebut, dapat dikatakan pendidikan Indonesia masih berada di urutan yang memprihatinkan. Ini menjadi peringatan terhadap kualitas pendidikan di Indonesia, yang menyebabkan banyak orang tua rela mengirim anaknya sekolah ke luar negeri. Dilihat dari skor yang dicapai pelajar usia 15 tahun (SMP) dalam kemampuan membaca, matematika, dan sains, Indonesia menjadi salah satu negara dengan peringkat terendah. Ini mempengaruhi pencapaian mutu pendidikan menurut survei Programme for International Study Assessment (PISA) pada 2012.

Data pendidikan tahun 2010 menyebutkan 1,3 juta anak usia 7-15 tahun terancam putus sekolah. Sistem pendidikan atau kurikulum di Indonesia masih sering berubah. Kurikulum pendidikan nasional yang dimulai sejak 1945, telah beberapa kali mengalami perubahan. Menurut data Kemendiknas 2010 akses pendidikan di Indonesia masih perlu mendapat perhatian, lebih dari 1,5 juta anak tiap tahun tidak dapat melanjutkan sekolah. Sementara dari sisi kualitas guru dan komitmen mengajar terdapat lebih dari 54\% guru memiliki standar kualifikasi yang perlu ditingkatkan dan 13,19\% bangunan sekolah dalam kondisi perlu diperbaiki.

Salah satu frasa sekolah adalah sekolah menengah atas kejuruan. Salah sau jurusan yang terdapat dalam sekolah menengah kejuruan adalah jurusan rekayasa perangkat lunak, yang mana sangat perlu menggunakan fasilitas belajar berbasis teknologi. Salah satu faktor keberhasilan dalam belajar ialah fasilitas belajar yang memadai (Suryasubrata, 1989, p.113). Untuk mencapai suatu prestasi belajar yang baik diperlukan proses belajar mengajar yang lancar, sedangkan proses belajar mengajar yang lancar harus didukung oleh lengkap tidaknya suatu fasilitas. Proses belajar mengajar akan berjalan lancar jika ditunjang oleh sarana yang lengkap, dari gedung sekolah sampai sarana yang dominan yaitu alat peraga (Widjaya, 1994).

\section{STUDI LITERATUR}

Fasilitas belajar adalah semua yang diperlukan dalam proses belajar mengajar baik bergerak maupun tidak bergerak agar tercapai tujuan pendidikan dapat berjalan dengan lancar, teratur, effektif, dan efisien (Muhroji, 2004). Dalyono (2001, p.241) menyatakan bahwa kelengkapan fasilitas belajar akan membantu siswa dalam belajar, dan kurangnya alat-alat atau fasilitas belajar akan menghambat kemajuan belajarnya. Fasilitas yaitu sarana yang diperlukan untuk meningkatkan kegiatan belajar mengajar. Lancar tidaknya proses belajar dipengaruhi oleh lengkap tidaknya suatu 
fasilitas. Proses belajar mengajar akan berjalan lancar jika ditunjang oleh sarana yang lengkap, dari gedung sekolah sampai sarana yang dominan yaitu alat peraga (Widjaya, 1994). Mohamad Surya (2004, p.80) memaparkan betapa pentingnya kondisi fisik fasilitas belajar terhadap proses belajar yang menyatakan bahwa, "Keadaan fasilitas fisik tempat belajar berlangsung di kampus, sekolah ataupun di rumah sangat mempengaruhi efisiensi hasil belajar.

Hasil belajar sering orang menyebutnya prestasi belajar menurut Muhibbin Syah (2008, p.141), "Prestasi belajar merupakan hasil dari sebagian faktor yang mempengaruhi proses belajar secara keseluruhan". Hasil Belajar menurut Nana Sudjana (2000, p.7), merupakan suatu kompetensi atau kecakapan yang dapat dicapai oleh siswa setelah melalui kegiatan pembelajaran yang dirancang dan dilaksanakan oleh guru di suatu sekolah dan kelas tertentu. Menurut Dimyati dan Mudjiono (2006, pp.3-4) Menyebutkan bahwa hasil belajar merupakan hasil dari suatu interaksi tindak belajar dan tindak mengajar. Hasil belajar juga dapat ditandai dengan perubahan tingkah laku (Aunurrahman 2012, p.36).

Faktor yang mempengaruhi prestasi belajar siswa salah satunya yaitu fasilitas belajar ( (Nasution, 1994, p.73). Menurut Violita Fanny (2013) Fasilitas belajar berpengaruh secara signifikan terhadap prestasi belajar siswa kelas $\mathrm{X}$ administrasi perkantoran di SMK $\mathrm{N} 1$ Payakumbuh. Berdasarkan penelitian yang lain (Lela Camellia, 2016) menyebutkan bahwa $47,9 \%$ prestasi belajar siswa pada mata pelajaran ekonomi dipengaruhi oleh fasilitas belajar dan motivasi belajar, sedangkan sisanya sebesar $52,1 \%$ (100\%-47,9\%) dipengaruhi oleh faktor lain yang tidak diteliti dalam penelitian seperti intelegensi siswa, sikap siswa, dan lingkungan sosial.

\section{METODE PENELITIAN}

Metode penelitian yang digunakan dalam penelitian ini adalah metode korelasi. Metode korelasi yaitu metode penelitian yang dilakukan dengan tujuan untuk menggambarkan dua atau lebih fakta dan juga sifat-sifat objek yang sedang diteliti. Metode tersebut dilakukan untuk membandingkan antar persamaan dengan perbedaan atau fakta berdasarkan kerangka pemikiran yang sudah ada shingga hasilnya dapat terlihat jelas.

Penelitian diadakan di Sekolah Menengah Kejuruan Negeri 5 Surakarta yang berada di Jl.Laksda Adi Sucipto, Manahan Surakarta. populasi yang digunakan adalah sebanyak 70 siswa kelas XI RPL yang terdiri dari kelas XI RPL A, XI RPL B, dan XI Axioo dengan sample sebanyak 58 orang. Teknik pengambilan data menggunakan kuisioner, observasi, dan dokumentasi. Uji instrumen yang digunakan yaitu (1) Uji Validitas dan (2) Uji Reliabilitas. Teknik analisis data yaitu (1) Uji Linieritas, (2) Uji Normalitas, dan (3) Uji Regresi.

\section{HASIL PENELITIAN DAN PEMBAHASAN}

\section{Hasil Penelitian}

Dalam penelitian ini didapatkan hasil $r=$ 0,277 dengan korelasi product moment yang menggunakan rumus di bawah ini :

$$
r=\frac{\sum x y}{\sqrt{\sum x^{2} y^{2}}} r=\frac{\sum x y}{\sqrt{\sum x^{2}}}
$$


Dimana :

$\mathrm{r}=$ Koefisien korelasi product moment antara variabel $\mathrm{X}$ dengan variabel $\mathrm{Y}$.

Untuk mengetahui ada tidaknya pengaruh variabel $\mathrm{X}$ terhadap variabel $\mathrm{Y}$ maka digunakan regresi linear sederhana dengan rumus $\mathrm{Y}=\mathrm{a}+$ bX. Untuk mencari a, digunakan rumus sebagai berikut :

$$
\begin{gathered}
a=\frac{\left(\sum Y\right)\left(\sum X^{2}\right)-\left(\sum X\right)\left(\sum X Y\right)}{n \sum X^{2}-\left(\sum X\right)^{2}} \\
b=\frac{n \sum X Y-\left(\sum X\right)\left(\sum Y\right)}{n \sum X^{2}-\left(\sum X\right)^{2}}
\end{gathered}
$$

Diperoleh persamaan regresinya adalah $\mathrm{Y}=$ 49,96 + 0,25X dimana : 49,96 adalah konstanta yang mempengaruhi prestasi belajar siswa tanpa dipengaruhi oleh perubahan nilai fasilitas belajar berbasis teknologi, 0,25 adalah koefisien regresi yang mempengaruhi prestasi belajar siswa.

\begin{tabular}{llll} 
& Table 1. Tabel Regresi \\
\hline & $\begin{array}{l}\text { Unstandardize } \\
\text { d Coefficients }\end{array}$ & $\begin{array}{l}\text { T } \\
\text { t }\end{array}$ \\
\hline Constant & 49,966 & 3,64 & 0,001 \\
& & 2 & \\
\hline Coefficient & 0,250 & 2,15 & 0,035 \\
s & 7 & \\
Regression & & & \\
\hline
\end{tabular}

Table 2. Tabel Data Kuisioner

\begin{tabular}{llllllll}
\hline & $\begin{array}{l}\text { Su } \\
\text { b } 1\end{array}$ & $\begin{array}{l}\text { Sub } \\
\mathbf{2}\end{array}$ & $\begin{array}{l}\text { Sub } \\
\mathbf{3}\end{array}$ & $\begin{array}{l}\text { Sub } \\
\mathbf{4}\end{array}$ & $\begin{array}{l}\text { Sub } \\
\mathbf{5}\end{array}$ & $\begin{array}{l}\text { Sub } \\
\mathbf{6}\end{array}$ & $\begin{array}{l}\text { Total } \\
\text { Sub }\end{array}$ \\
\hline $\begin{array}{l}\text { Sanga } \\
\text { t }\end{array}$ & 11 & 13 & 17 & 1 & 37 & 22 & 101 \\
Setuju & & & & & & \\
\hline Setuju & 16 & 29 & 33 & 8 & 20 & 33 & 139 \\
\hline Netral & 17 & 14 & 5 & 34 & 0 & 3 & 73 \\
\hline $\begin{array}{l}\text { Tidak } \\
\text { Setuju }\end{array}$ & 2 & 3 & 14 & 1 & 0 & 28 \\
\hline $\begin{array}{l}\text { Sangat } \\
\text { Tidak } \\
\text { Setuju }\end{array}$ & 0 & 0 & 1 & 0 & 0 & 7 \\
\hline Total & 58 & 58 & 58 & 58 & 58 & 58 & 58 \\
\hline
\end{tabular}

Dari tabel di atas dapat dilihat yaitu jumlah jawaban sangat setuju sebanyak 101 orang, jawaban setuju sebanyak 139 orang, jawaban netral sebanyak 73 orang, jawaban tidak setuju sebanyak 28 orang, dan jawaban sangat tidak setuju sebanyak 7 orang.

Table 3. Tabel Prestasi Belajar

\begin{tabular}{llll}
\hline $\begin{array}{l}\text { Kuartil } \\
\text { Atas }\end{array}$ & $\begin{array}{l}\text { Kuartil } \\
\text { Bawah }\end{array}$ & \multicolumn{2}{c}{ Rata-rata } \\
\hline KKM \\
\hline 98 & 53 & 79,3 & 76 \\
\hline
\end{tabular}

\section{Pembahasan}

Dari hasil penyajian data menunjukkan bahwa fasilitas belajar berbasis teknologi di SMKN 5 Surakarta sudah baik. Sebagai contoh bisa dilihat dari ketersediaan fasilitas jaringan berbasis internet yang biasa disebut wifi sudah tersedia dengan baik. Jaringan wifi sudah memenuhi hampir di setiap ruangan di seluruh sekolah. Bahkan sinyal wifi sudah mencakup di area tanah lapang. Penggunaan wifi juga bisa dimanfaatkan oleh siswa, guru, karyawan sekolah. Terdapat dua jenis jaringan, yaitu dari penyedia layanan internet berbasis telkom dan internet berbasis biznet. Meskipun telah tersedia dua buah jaringan dengan ISP yang berbeda, namun hal tersebut menurut siswa dirasa kurang bisa memenuhi kebutuhan siswa. Hal tersebut dikarenakan jaringan wifi menggunakan jaringan wireless yang mana sinyal dapat berubah sewaktu-waktu dan hasilnya kecepatan internet juga naik turun. Selain itu juga faktor bandwith yang terbilang kurang berdasarkan jumlah access point terhadap jumlah siswa juga memicu kecepatan internet dalam hal untuk memenuhi kebutuhan siswa. Selain 
menggunakan fasilitas berbasis teknologi internet, siswa juga masih menggunakan fasilitas konvensional, yang mana dalam hal ini adalah buku. Di SMK 5 Surakarta menyediakan fasilitas belajar perpustakaan, yang mana koleksi buku di sana sudah bisa dibilang cukup lengkap. Akan tetapi jumlah siswa yang menggunakan fasilitas konvensional buku lebih sedikit dibandingkan dengan siswa yang menggunakan fasilitas berbasis teknologi seperti internet. Terlepas dari fasilitas belajar berbasis teknologi internet wifi, di sekolah tersebut juga sudah terdapat jaringan LAN (Local Area Network) yang mana fasilitas tersebut sudah hampir menyeluruh. Untuk lab komputer sudah terdapat masing-masing satu port untuk tiap komputer dan di kelas Axioo sudah ada port di masing-masing meja siswa.

Meskipun menggunakan metode moving class namun media pembelajaran yang digunakan sudah baik. Penggunaan LCD di setiap kelas sudah berjalan. Dengan menggunakan LCD dalam proses kegiatan belajar mengajar tentunya siswa dapat menerima materi yang disampaikan oleh guru lebih baik dibandingkan dengan menyampaikan materi menggunakan metode ceramah. Selain pengunaan $\mathrm{LCD}$, penggunaan pengeras suara juga sudah diterapkan. Hal tersebut bisa dilihat di setiap kelas sudah terdapat speaker. Seluruh fasilitas belajar yang tersedia baik itu jaringan wifi, pengeras suara, dan LCD dapat dipergunakan dengan baik.

Selain tersedianya fasilitas belajar berbasis teknologi dengan baik, fasilitas tersebut juga didukung penuh oleh pengajar / guru. Dengan menggunakan fasilitas belajar berbasis teknologi yang ada, maka pekerjaan guru dapat diselesaikan dengan baik dan sesuai harapan. Dalam menggunakan fasilitas belajar berbasis teknologi, guru RPL di SMKN 5 sudah memiliki keahlian dan sudah berpengalaman. Bahkan ada guru yang sudah mendapatkan sertifikat di dalam fasilitas belajar berbasis teknologi dalam hal ini adalah internet. Banyaknya tugas tidak menghambat guru dalam menyelesaikan tugasnya. Hal itu dikarenakan menggunakan fasilitas berbasis teknologi. Selain itu guru juga lebih mudah menyampaikan suatu materi pembelajaran di kelas.

Dengan menggunakan fasilitas berbasis teknologi internet, proses pencarian tugas-tugas sekolah oleh siswa dapat dilakukan dengan dengan cepat. Akan tetapi kecepatan pencarian tugas juga dipengaruhi oleh bandhwith dan juga situs penyedia layanan seperti blog, forum dan media sosial. Sebagai contoh siswa diberikan tugas oleh guru. Dengan menggunakan jaringan internet berbasis LAN tentunya koneksi akan lebih baik dari pada siswa yang menggunakan jaringan internet berbasis wifi. Selain itu juga kondisi situs pencarian tugas juga mempengaruhi. Situs yang menggunakan bahasa asing akan lebih sulit dipahami daripada yang menggunakan bahasa Indonesia. Menggunakan internet dalam mengerjakan tugas yang diberikan oleh guru juga akan memberikan pemahaman yang lebih cepat dan lebih baik. Hal tersebut dikarenakan di dalam internet bisa terdapat teks, gambar, suara, dan video yang mana lebih baik daripada menggunakan buku yang memuat teks dan gambar saja. Penggunaan fasilitas berbasis internet juga bisa membuat siswa menemukan hal yang baru. Sebagai contoh dengan menggunakan fasilitas internet siswa 
dapat berkomunikasi dan berdiskusi dengan siswa lain ataupun dengan orang umum melalui sebuah forum. Dengan berdiskusi dan bertukar pikiran maka dapat menimbulkan pengetahuan baru diantara kedua belah pihak. Selain itu juga bisa bekerjasam membangun atau mengembangkan materi yang telah diajarkan oleh guru.

Berdasarkan hasil data yang diperoleh maka fasilitas belajar berbasis teknologi dapat membantu siswa dalam menyelesaikan tugas yang diberikan oleh guru secara maksimal. Tugas tersebut bisa dikerjakan dengan bantuan internet. Dengan mengerjakan tugas yang diberikan oleh guru secara maksimal maka efektifitas belajar siswa akan lebih baik. Selain itu siswa juga dapat mengaplikasikan materi yang disampaikan oleh guru. Sebagai contoh guru memberikan materi tentang pembuatan tabel di dalam HTML, dengan mengembangkannya maka siswa dapat membuat website sederhana. Siswa juga bisa belajar secara mandiri, baik itu kapanpun dan dimanapun. Berdasarkan data yang telah diperoleh tingkat prestasi belajar siswa di SMK N 5 Surakarta khususnya kelas XI RPL pada mata pelajaran pemrograman web adalah baik. Hal tersebut dibuktikan dengan nilai rata-rata siswa semuanya di atas kriteria ketuntasan minimal (KKM). Sedangkan fasilitas belajar khususnya berbasis teknologi juga baik. Fasilitas tersebut sudah lengkap dan dalam keadaan yang baik juga.

Untuk menentukan apakah koefisien korelasi signifikan atau tidak maka perlu dibandingkan dengan $\mathrm{r}$ tabel ( tabel $\mathrm{r}$ product moment) dengan ketentuan :
H0: Tidak ada hubungan antara fasilitas belajar berbasis teknologi dengan prestasi belajar siswa.

Ha: Ada hubungan antara fasilitas belajar berbasis teknologi dengan prestasi belajar siswa. Berdasarkan Hasil penelitian maka diperoleh $r$ hitung $\geq r_{\text {tabel }}$, korelasi signifikan. Bila ditetapkan taraf kesalahan 5\% (taraf kepercayaan 95\%) dan $\mathrm{N}=58$ diperoleh $\mathrm{r}_{\text {tabel }}: 0,2586$. Ternyata $\mathrm{r}_{\text {hitung }}$ $(0,277) \geq r_{\text {tabel }}(0,2582)$ sehingga $h_{0}$ ditolak dan $\mathrm{h}_{\mathrm{a}}$ diterima. Dapat diinterpretasikan bahwasanya ada korelasi positif dan signifikan sebesar 0,277 antara fasilitas belajar berbasis teknologi dengan prestasi belajar siswa kelas. Berarti semakin tinggi fasilitas belajar maka semakin tinggi juga prestasi belajar. Besar sumbangan variabel $\mathrm{X}$ terhadap Y yaitu koefisien determinasinya yang mana $r^{2}=(0,277)^{2}=0,077$. Hal ini berarti varians yang terjadi pada variabel prestasi belajar 7\% dapat dijelaskan melalui varians pada variabel fasilitas belajar, atau prestasi belajar $7,7 \%$ ditentukan oleh fasilitas belajar sedangkan 92,3\% oleh faktor lainnya.

Pengujian menggunakan uji dua sisi dengan tingkat signifikansi $\alpha=5 \%$. (uji dilakukan 2 sisi karena untuk mengetahui ada atau tidaknya pengaruh yang signifikan, jika 1 sisi digunakan untuk mengetahui hubungan lebih kecil atau lebih besar). Tingkat signifikansi dalam hal ini berarti kita mengambil risiko salah dalam mengambil keputusan untuk menolak hipotesa yang benar sebanyak-banyaknya 5\% dengan rumus sebagai berikut :

$$
t=\frac{r \sqrt{n-2}}{\sqrt{1-r^{2}}}
$$

Syarat : 
Bila $\mathrm{t}$ hitung $\leq \mathrm{t}$ tabel maka $\mathrm{H}_{0}$ diterima atau korelasinya tidak signifikan, jika $\mathrm{t}_{\text {hitung }} \geq \mathrm{t}$ tabel maka $\mathrm{H}_{\mathrm{a}}$ ditolak atau korelasi signifikan :

$t=\frac{0,277 \sqrt{58-2}}{\sqrt{1-0,277^{2}}}$

$t=\frac{0,277(7,48)}{\sqrt{1-0,277^{2}}}$

$t=2,15$

H0: Tidak terdapat pengaruh antara fasilitas belajar berbasis teknologi dengan prestasi belajar siswa.

Ha: Terdapat pengaruh antara fasilitas belajar berbasis teknologi dengan prestasi belajar siswa.

Untuk kesalahan $5 \%$ uji dua pihak dan $\mathrm{dk}=\mathrm{n}-$ $1=57$, maka diperoleh ttabel $=2,00247$, maka $\mathrm{t}$ hitung $\geq \mathrm{t}$ tabel yang mana $\mathrm{H} 0$ ditolak dan $\mathrm{Ha}$ diterima atau korelasi signifikan. Dari hasil perhitungan didapatkan bahwa pengaruh antara fasilitas belajar berbasis teknologi dengan prestasi belajar ternyata positif dan lemah, hal ini dapat dibuktikan dengan $r=0,2737$ dimana pedoman untuk memberikan interpretasi yang dikemukakan oleh Sugiyono berada pada interval 0,20 - 0,399 yang termasuk dalam kategori rendah.

Table 3. Hasil Analisis Hipotesis

\section{dk Taraf Thitung Ttabel Hipotesis Kesalahan}

$985 \%(0.05) \quad 2,15 \quad 2,00247$ Diterima

Adapun analisis data tentang regresi yang sebelumnya yaitu interpretasinya adalah peningkatan fasilitas belajar berbasis teknologi akan diikuti dengan peningkatan prestasi belajar, persamaan regresi tersebut memberikan informasi bahwa jika tidak ada fasilitas belajar berbasis teknologi maka indeks prestasi belajar sebesar 49,96. Jika terjadi atau ada peningkatan fasilitas belajar berbasis teknologi maka prestasi belajar akan meningkat juga.

Berdasarkan analisis-analisis di atas maka hipotesis yang penulis ajukan yaitu terdapat pengaruh antara fasilitas belajar berbasis teknologi dengan prestasi belajar siswa dapat diterima dan terbukti kebenarannya. Sesuai dengan penelitian sebelumnya yaitu terdapat pengaruh positif dan signifikan fasilitas belajar, motivasi dan minat belajar secara bersama-sama terhadap prestasi belajar siswa oleh Pekik Wicaksono (2012). Diperkuat juga oleh penelitian Ambarsari Iis (2013) bahwa kelengkapan fasilitas belajar dan kemandirian belajar secara bersama-sama berpengaruh terhadap prestasi belajar ekonomi. Besarnya pengaruh fasilitas belajar dan kemandirian adalah 28,8 \%. Selain itu juga ada pengaruh yang positif antara fisilitas belajar dengan prestasi belajar Pendidikan Pancasila dan kewarganegaraan (PPKn) murid kelas V SDN 53 Sawerigading. Besarnya koefisien korelasi antara kedua variable tersebut di atas yaitu 0.2602 dengan koefisien determinasinya sebesar $6.77 \%$ (Hasnah). Fasilitas sekolah maupun lingkungan sosial secara parsial berpengaruh signifikan terhadap hasil belajar siswa kelas XI dan XII IPS 1 MAN 1 Madiun. Hasil uji nilai selisih mutlak menunjukan bahwa variabel lingkungan sosial merupakan vaiabel pemoderasi yang mampu memperkuat pengaruh fasilitas sekolah terhadap hasil belajar siswa. Secara simultan variabel fasilitas sekolah dan lingkungan sosial bepengaruh terhadap hasil belajar siswa (Nik amah \& Angga Dwi, 2015). 


\section{SIMPULAN, IMPLIKASI, DAN SARAN}

\section{Simpulan}

Berdasarkan hasil penelitian dan pembahasan, maka dapat diambil suatu kesimpulan sebagai berikut :

1. Terdapat pengaruh positif yang signifikan sebesar 0,27 antara fasilitas belajar berbasis teknologi dengan prestasi belajar siswa pada mata pelajaran pemrograman web kelas XI RPL di SMKN 5 Surakarta.

2. Fasilitas belajar berbasis teknologi di SMKN 5 Surakarta berada pada kategori yang baik, dimana fasilitas sudah lengkap dan dalam kondisi yang baik.

3. Tingkat prestasi siswa di SMKN 5 Surakarta khususnya kelas XI RPL pada mata pelajaran pemrograman web adalah baik. Hal tersebut berdasarkan indeks nilai siswa kelas XI RPL di SMKN 5 Surakarta dalam mata pelajaran pemrograman web rata-rata berada di atas batas kriteria ketuntasan minimal yaitu sebesar 76 .

\section{Implikasi}

Suatu penelitian yang telah dilakukan di ruang lingkup pendidikan maka kesimpulan yang ditarik tentu mempunyai implikasi di dalam pendidikan juga dan penelitian-penelitian selanjutnya, sehubungan dengan hal tersebut maka implikasinya adalah sebagai berikut :

1. Hasil penelitian mengenai variabel fasilitas belajar berbasis teknologi dengan variabel prestasi belajar mempunyai hubungan yang signifikan, namun hanya memberikan kontribusi $7 \%$ saja. Kontribusi tersebut dikarenakan kurangnya siswa dalam memaksimalkan penggunaan fasilitas belajar berbasis teknologi.

2. Indeks prestasi belajar tidak semata-mata dipengaruhi oleh fasilitas belajar berbasis teknologi saja, namun juga dipengaruhi oleh faktor lain, sehubungan dengan hal tersebut perlu diteliti lebih lanjut tentang faktor-faktor lain yang diduga mempengaruhi prestasi belajar siswa.

\section{Saran}

Dalam penelitian dapat dilihat bahwa hasil penelitian masih belum bisa berjalan secara maksimal, meskipun sudah mendekati kata maksimal. Untuk itu saran yang dapat diberikan adalah :

1. Siswa perlu menggunakan fasilitas belajar berbasis teknologi secara maksimal.

2. Pengajar / guru perlu mengetahui dan berpengalaman dalam menggunakan fasilitas belajar berbasis teknologi khususnya dalam hal kegiatan belajar mengajar.

3. Pihak sekolah hendaknya menjaga dan meningkatkan fasilitas belajar berbasis teknologi, karena hal tersebut memberikan pengaruh positif terhadap prestasi belajar siswa.

4. Perlu diteliti lebih lanjut tentang faktor-faktor lain selain fasilitas belajar berbasis teknologi yang diduga mempengaruhi prestasi belajar siswa

\section{DAFTAR PUSTAKA}

Ambarwati, Iis (2013). Pengaruh kelengkapan Fasilitas Belajar dan Kemandirian Belajar terhadap Prestasi Belajar Ekonomi pada Siswa Kelas X SMA Negeri 2 Sukoharjo Tahun Ajaran 2012/2013.

Aunurrahman. (2012). Belajar dan 
Pembelajaran. Bandung: Alfabeta.

Bambang Eka Purnama. (2014). Cara mudah membuat web dengan CMS. Yogyakarta: Graha Ilmu.

Burham, N. (2012). Penilaian Pembelajaran Bahasa Berbasis Kompetensi. Yogyakarta: BPFE-Yogyakarta.

Camellia, L. (2016). Pengaruh Fasilitas Belajar dan Motivasi Belajar terhadap Prestasi belajar di SMA N 5 Surakarta. Surakarta : FKIP UNS.

Dalyono. (2001). Psikoloi Pendidikan. Jakarta: Rineka Cipta.

Dimyati dan Mudjiono. (2009). Belajar dan Pembelajaran. Jakarta: Rineka Cipta.

Eny Dwi Suharyati, (2013). Fasilitas Pendidikan Berbasis Teknologi Terhadap Efektifitas Belajar Mahasiswa Ilmu Sosial Politik Universitas Mulawarman Samarinda. Samarinda : eJournal Ilmu Administrasi, 2013, 1 (2): 737-748

Fraenkel dan Wellen. (2008). How To Design And Evaluate Research In Education. New York: McGraw-Hill.

Hamalik, O. (2003). Proses Belajar Mengajar. Jakarta: Bumi Aksara.

Kamus besar bahasa Indonesia. (2001). jakarta: Balai pustaka.

Mansyur, R. dan. (2008). Penilaian Hasil Belajar. Bandung: CV.Wacana Prima.

Muhroji. (2004). Manajemen Pendidikan. Surakarta: FKIP UMS.

Mulyasa. (2007). Standar Kompetensi dan Sertifikasi Guru. Bandung: Rosda Karya.

Nasution, M. (1994). Teknologi Pendidikan. Jakarta: Djambatan.

Singarimbun, Masri dan Sofian Effendi, Metode Penelitian Survei, Jakarta: LP3ES, 2008.

Sudjana, N. (2000). Penilaian Hasil Belajar. Bandung: Rosda Karya.

Sugiyono. (2007). Metode Penelitian Administrasi. Bandung: Alfabeta.
Sugiyono. (2012). Metode Penelitian Kuantitatif Kualitatif, Dan R\&D. Bandung: Alfabeta.

Sugiyono. (2015). Metode Penelitian Kuantitatif Kualitatif, Dan R\&D. Bandung: Alfabeta.

Sugono, D. (2008). Kamus Bahasa Indonesia. Jakarta: Pusat Bahasa Depdiknas.

Suharsimi, A. (2010). Prosedur Penelitian, suatu pendekatan praktik. Jakarta : Rinneka Cipta.

Suprayekti. (2003). Interaksi Belajar Mengajar. Jakarta: Direktorat Tenaga Kependidikan, Dikdasmen, Depdiknas.

Suryasubrata. (1989). Proses Belajar Mengajar Di Perguruan Tinggi. Yogyakarta: Andi Offset.

Suryasubrata. (2004). Psikologi Pembelajaran dan Pengajaran. Bandung: Pustaka Bani Quraisy.

Sutikno, S. (2013). Belajar dan Pembelajaran. Lombok: Holistika.

Suwartono (2014). Dasar-dasar metodologi penelitian. Yogyakarta: Andi Offset.

Syah, M. (2008). Psikologi Pendidikan Dengan Pendekatan Baru. Bandung: Rosda Karya.

The Liang Gie. (2002). Cara Belajar Yang Efisien. Yogyakarta: Pusat Kemajuan Studi.

Violita, F. (2013). Pengaruh Lingkungan Keluarga dan Fasilitas Belajar terhadap Prestasi Belajar Siswa Kelas X Administrasi Perkantoran di SMKN 1 Payakumbuh.

Wicaksono Pekik (2102). Pengaruh Fasilitas Belajar, Motivasi Belajar, dan Minat Belajar terhadap Prestasi Belajar Siswa Kelas X SMK Muhammadiyah Prambanan Tahun Ajaran 2011/2012.

Widjaya. (1994). Sarana Pendidikan. Bandung: Tarsito. 